\title{
Assessment of knowledge and attitude about emergency contraception: a cross sectional study among medical students in North India
}

\author{
Rajiv Kumar Gupta ${ }^{1 *}$, Parveen Singh¹, Rashmi Kumari', Bhavna Langer ${ }^{1}$, \\ Pawan Sharma ${ }^{1}$, Riya Gupta ${ }^{2}$
}

\begin{abstract}
${ }^{1}$ Department of Community Medicine, Government Medical College, Jammu, Jammu and Kashmir, India
${ }^{2}$ Department of Community Medicine, Acharya Shri Chander College of Medical Sciences and Hospital, Sidhra, Jammu, Jammu and Kashmir, India
\end{abstract}

Received: 07 July 2017

Accepted: 05 August 2017

\section{*Correspondence:}

Dr. Rajiv Kumar Gupta,

E-mail: rajivguptagmc@ rediffmail.com

Copyright: $($ ) the author(s), publisher and licensee Medip Academy. This is an open-access article distributed under the terms of the Creative Commons Attribution Non-Commercial License, which permits unrestricted non-commercial use, distribution, and reproduction in any medium, provided the original work is properly cited.

\begin{abstract}
Background: Emergency contraception (EC) which is the only method indicated after the unprotected sexual intercourse prevents unintended pregnancies and its harmful consequences like unsafe abortion or unintended child delivery. Since medical students are the future medical professional and would be the main channel to provide preventive, promotive and curative services to the population at large, their knowledge and attitude towards EC is an important context in the overall health scenario of India. The study aimed to assess the knowledge and attitudes of medical students towards use of EC.

Methods: This cross sectional questionnaire based study was conducted among 2nd professional MBBS students in a Government Medical College in North India. The self administered questionnaire intended to seek information on knowledge and attitude of the students. The data so collected was expressed in percentages and Chi square test was used as test of significance.

Results: All the respondents had heard of EC with mass media as the main source of information. More than $90 \%$ of the respondents knew about the indications for use of EC as well as the timing of the use of EC. Female respondents had better knowledge about composition of EC as well mechanism of action $(\mathrm{p}<0.05)$. More than $90 \%$ would recommend EC in case of unprotected sexual intercourse and $83.5 \%$ had positive attitude towards EC.

Conclusions: Although knowledge about EC was good on certain parameters, yet lack of in depth knowledge among future health care providers is a cause of concern. So, attention be given to special issues relating to EC from early years of medical education till internship.
\end{abstract}

Keywords: Attitude, Emergency contraception, Knowledge

\section{INTRODUCTION}

Emergency contraception (EC) also known as post-coital contraception or morning after pill - refers to a group of birth control contraceptive modalities which is indicated after unprotected sexual intercourse. EC is vital for the prevention of unintended pregnancy which in turn would reduce unintended child birth and safe abortion; both of which are major problem of maternal health. ${ }^{1}$ EC is effective if used preferably within 72 hours of sexual intercourse. $^{2}$

Two types of ECs are- emergency contraceptive pills and intrauterine devices (IUDs). The pills used as EC may be combined oral contraceptive pills or a progestin only pill. 
IUDs as EC are effective if used within 5 days of unprotected sexual intercourse. ${ }^{3}$ EC is intended for occasional or emergency use only and not as a regular contraception. As far mode of action is concerned, EC works by preventing fertilization, implantation and tubal transportation of sperm and ovum.

Globally, out of 250 million pregnancies every year, one third are unintended and about $20 \%$ of these undergo induced abortion. In low income countries, about two third of unintended pregnancies are due to non use of contraceptives and more than 100 million married females have unmet need for contraception. ${ }^{4}$ Each year about 68000 women die due to unsafe abortion and millions end up with many complications of unsafe abortion - this could have been averted or reduced by the use of EC.

Although a variety of modern contraceptives exist, yet the unintended pregnancies remain a cause of concern. Reasons for such pregnancies could be due to gap in awareness, negative attitude towards contraception, low accessibility, sexual assault and / or rarely failure of contraception. ${ }^{5}$ Even when knowledge and practice is present, there is need to have EC as a backup method since none of the contraceptive is $100 \%$ effective.

In the current scenario where there is evidence of increasing adolescent sexual activity and decreasing age at first sex in developing countries, the role of EC has assumed great importance. ${ }^{6}$ In order to increases the public health benefits of EC, it is of paramount importance that the potential users as well as prescribers be well informed about the availability and use of EC.

Medical students who are the future health care providers need to have adequate knowledge and positive attitude towards EC as it has implications to large number of people they will cater in near future. Given the importance of EC, the purpose of this study was to assess the knowledge and attitudes of undergraduate medical students in a Government Medical College in North India.

\section{METHODS}

This cross-sectional study was conducted in March 2017 in a Government Medical College in Jammu region after taking ethical clearance from Institutional Ethics Committee. The questionnaire was prepared by public health experts of Government Medical College Jammu giving due consideration to knowledge and attitude of medical students towards EC. The previous studies were used for preparation of the questionnaire and to increase the quality and validity of the data. The questionnaire was tested on a small group of students who didn't form the part of the study group. After incorporating the necessary recommendations, the questionnaire was finally used to interview the study participants.
The questionnaire consists of three parts. First part consists of 6 questions on demographics, second part 11 questions on knowledge and third part 9 questions on attitude.

The study participants were II year MBBS students $\left(4^{\text {th }}\right.$ $5^{\text {th }}$ semesters) which are 150 in strength as per normal guidelines. On the day, the questionnaire was administered, 134 students were present. The purpose of the study was explained to all the study participants and written informed consent was obtained from each of them. They were further informed that all their responses are confidential and anonymous and they have the right not to be involved in the study or not to answer any of the questions. The data was collected while students were in class rooms. The instructors helped the principal investigator in disseminating the questionnaire. The responses were collected and checked for completeness by the principal investigator in the end.

\section{Statistical analysis}

The data thus collected was tabulated and analysed. Test of significance used was the Pearson's Chi square test and $p<0.05$ was considered statistically significant.

\section{RESULTS}

The present study was conducted among 134 medical undergraduate students of $2^{\text {nd }}$ professional MBBS.

Table 1: Socio-demographic variables of the respondents $(n=134)$.

\begin{tabular}{|l|l|}
\hline Socio-demographic variable & Frequency $(\%)$ \\
\hline Sex & $61(45.52)$ \\
\hline Male & $73(54.48)$ \\
\hline Female & \\
\hline Age & $64(47.76)$ \\
\hline$<20$ years & $70(52.24)$ \\
\hline$>20$ years & \\
\hline Religion & $74(55.22)$ \\
\hline Hindu & $51(38.06)$ \\
\hline Muslim & $06(4.48)$ \\
\hline Sikh & $03(2.24)$ \\
\hline Others & \\
\hline Residence & $58(43.28)$ \\
\hline Rural & $76(56.72)$ \\
\hline Urban & $68(50.75)$ \\
\hline Family income & $48(35.82)$ \\
\hline$<50000$ & $18(13.43)$ \\
\hline $50000-1$ lakh & $02(1.49)$ \\
\hline$>1$ lakh & $14(10.45)$ \\
\hline Maternal literacy & $24(17.91)$ \\
\hline Illiterate & $40(29.86)$ \\
\hline Up to Middle & $54(40.29)$ \\
\hline Up to SSC & \\
\hline Up to HSC & \\
\hline Graduate and above & \\
\hline
\end{tabular}


Among the respondents 54.4\% were females, 52.2\% were aged more than 20 years and $55.2 \%$ belonged to Hindu religion. Of the total, $56.7 \%$ belonged to urban areas and half of them had family income below fifty thousand rupees. Regarding maternal literacy of the respondents, $40 \%$ were found to be graduate and above (Table 1). All the respondents, both males and female had heard about
EC. Mass media was the main source of information both in males as well as females ( $>>0.05)$. Awareness regarding use of OCP as EC was $72.3 \%$ while usage of IUCD as EC was only $9.70 \%$ among the respondents. Awareness regarding OCP and IUCD both as EC tools was also very dismal to the tune of $12.69 \%$ ( $p>0.05)$.

Table 2: Awareness of respondents regarding emergency contraception $(n=134)$.

\begin{tabular}{|c|c|c|c|c|c|}
\hline Question & Response & Male $(n=61)$ & $\begin{array}{l}\text { Female } \\
(\mathrm{n}=73)\end{array}$ & $\begin{array}{l}\text { Total } \\
(\mathrm{n}=134)\end{array}$ & $P$ value \\
\hline \multirow{2}{*}{$\begin{array}{l}\text { Have you heard of emergency } \\
\text { contraceptives }\end{array}$} & Yes & $61(100)$ & $73(100)$ & $134(100)$ & \multirow{6}{*}{0.09} \\
\hline & No & $00(0.00)$ & $00(0.00)$ & $00(0.00)$ & \\
\hline \multirow{4}{*}{ If yes source of information } & Friends & $09(14.75)$ & $04(5.48)$ & $13(9.70)$ & \\
\hline & Mass media & $31(50.82)$ & $49(67.12)$ & $80(59.70)$ & \\
\hline & Health institution & $16(26.22)$ & $18(24.66)$ & $34(25.37)$ & \\
\hline & Others & $05(8.19)$ & $02(2.74)$ & $07(5.22)$ & \\
\hline \multirow{4}{*}{$\begin{array}{l}\text { Which of these can be used as } \\
\text { emergency contraceptives }\end{array}$} & OCP & $45(73.77)$ & $52(71.23)$ & $97(72.39)$ & \multirow{4}{*}{0.72} \\
\hline & IUCD & $07(11.48)$ & $06(8.22)$ & $13(9.70)$ & \\
\hline & Both & 07 (11.48) & $10(13.69)$ & $17(12.69)$ & \\
\hline & Others & $02(3.28)$ & $05(6.85)$ & $7(5.22)$ & \\
\hline \multirow{3}{*}{$\begin{array}{l}\text { Indication for use of emergency } \\
\text { contraceptives }\end{array}$} & Unprotected sex & $30(49.18)$ & $40(54.79)$ & $70(52.24)$ & \multirow{3}{*}{0.54} \\
\hline & Unwanted pregnancy & $27(44.26)$ & $26(35.62)$ & $53(39.55)$ & \\
\hline & Don't know & $04(6.56)$ & $07(9.59)$ & $11(8.21)$ & \\
\hline \multirow{3}{*}{$\begin{array}{l}\text { Maximum acceptable time for women } \\
\text { to take emergency contraceptives }\end{array}$} & Any time & $03(4.92)$ & $02(2.73)$ & $05(3.73)$ & \multirow{3}{*}{0.61} \\
\hline & Within 72 hours & $55(90.16)$ & $65(89.04)$ & $120(89.55)$ & \\
\hline & Don’t know & $03(4.92)$ & $06(8.22)$ & $09(6.72)$ & \\
\hline \multirow{4}{*}{$\begin{array}{l}\text { Drug composition of emergency } \\
\text { contraceptives in comparison to regular } \\
\text { pills }\end{array}$} & Same as OCP & $09(14.75)$ & $05(6.85)$ & $14(10.45)$ & \multirow{4}{*}{0.01} \\
\hline & $\begin{array}{l}\text { High dose of } \\
\text { hormones }\end{array}$ & $36(59.02)$ & $61(83.56)$ & $97(72.39)$ & \\
\hline & Completely different & $05(8.19)$ & $02(2.74)$ & $07(5.22)$ & \\
\hline & Don't know & $11(18.03)$ & $05(6.85)$ & $16(11.94)$ & \\
\hline \multirow{4}{*}{$\begin{array}{l}\text { Mechanism of action of emergency } \\
\text { contraceptives }\end{array}$} & It prevents implantation & $24(39.34)$ & $33(45.21)$ & $57(42.54)$ & \multirow{4}{*}{0.01} \\
\hline & $\begin{array}{l}\text { Prevents implantation } \\
\text { and ovulation }\end{array}$ & $14(22.95)$ & $29(39.73)$ & $43(32.09)$ & \\
\hline & Induce abortion & $13(21.31)$ & $04(5.47)$ & $17(12.68)$ & \\
\hline & Don’t know & $10(16.39)$ & $07(9.59)$ & $17(12.68)$ & \\
\hline \multirow{3}{*}{$\begin{array}{l}\text { Is the pregnancy test necessary before } \\
\text { prescription of emergency } \\
\text { contraceptives }\end{array}$} & Yes & $30(49.18)$ & $18(24.66)$ & $48(35.82)$ & \multirow{3}{*}{0.00} \\
\hline & No & $20(32.79)$ & $42(57.53)$ & $62(46.27)$ & \\
\hline & Don’t know & $11(18.03)$ & $13(17.81)$ & $24(17.91)$ & \\
\hline \multirow{4}{*}{$\begin{array}{l}\text { Effectiveness of emergency } \\
\text { contraceptives in prevention of } \\
\text { pregnancy }\end{array}$} & Very good (>95\%) & $11(18.03)$ & $08(10.96)$ & $19(14.18)$ & \multirow{4}{*}{0.00} \\
\hline & Good $(75-90 \%)$ & $32(52.46)$ & $11(15.07)$ & $43(32.09)$ & \\
\hline & Fair $(50-75 \%)$ & $05(8.19)$ & $13(17.81)$ & $18(13.43)$ & \\
\hline & Don't know & $13(21.31)$ & $41(56.16)$ & $54(40.29)$ & \\
\hline \multirow{4}{*}{$\begin{array}{l}\text { Safety profile of emergency } \\
\text { contraceptives }\end{array}$} & Very safe & $02(3.28)$ & $08(10.96)$ & $10(7.46)$ & \multirow{4}{*}{0.08} \\
\hline & Safe & $24(39.34)$ & $36(49.32)$ & $60(44.78)$ & \\
\hline & Cause health problem & $15(24.59)$ & $16(21.92)$ & $31(23.13)$ & \\
\hline & Not sure & $20(32.79)$ & $13(17.81)$ & $33(24.63)$ & \\
\hline \multirow{3}{*}{$\begin{array}{l}\text { Is the emergency contraceptive easily } \\
\text { procured from any retail outlets }\end{array}$} & Yes & $36(59.02)$ & $35(47.95)$ & $71(52.99)$ & \multirow{3}{*}{0.00} \\
\hline & No & $18(29.51)$ & $11(15.07)$ & $29(21.64)$ & \\
\hline & Don't know & 07 (11.47) & $27(36.98)$ & $34(25.37)$ & \\
\hline
\end{tabular}


Regarding indication for use of EC, $52.2 \%$ were aware of its use against unprotected sex while $39.5 \%$ were aware that it could prevent unwanted pregnancy. Only $8.2 \%$ of the respondents didn't know the indications for use of EC ( $>>0.05)$. About $90 \%$ of the respondents knew that EC was to be taken within 72 hours of unprotected sex. Regarding drug composition of EC, higher proportion of female respondents knew that it contained high doses of hormones than the male counterparts (83.5\% vs. $59.02 \%)$ and this difference among the sexes was found to be statistically significant $(\mathrm{p}<0.05)$. The female respondents also had better knowledge about mechanism of action of EC which was statistically significant $(p<0.05) .57 .5 \%$ of female respondents knew that pregnancy test was not required before using EC in comparison to only $32.7 \%$ of the male respondents. This difference of knowledge among the male and female students was found to be statistically significant $(\mathrm{p}<0.05)$.

$40.2 \%$ of the respondents didn't know about the effectiveness of the EC against prevention of pregnancy. Among those who aware, it was found that males had better knowledge than their female counterparts and this difference of knowledge among the students of either sexes was statistically significant $(\mathrm{p}<0.05)$. About $45 \%$ of the respondents rated EC as safe while $25 \%$ replied that they weren't sure. As far as availability of EC was concerned, $53 \%$ respondents were aware about it while $25 \%$ of them didn't know about it. The awareness about availability was more in males and in statistical significance, it came to be highly significant $(\mathrm{p}<0.00)$ (Table 2).

Table 3: Attitude of respondents regarding emergency contraceptives $(n=134)$.

\begin{tabular}{|c|c|c|c|c|c|}
\hline Question & Response & Male $(n=61)$ & Female $(n=73)$ & Total $(n=134)$ & P value \\
\hline \multirow{2}{*}{$\begin{array}{l}\text { If a close friend or a relative has } \\
\text { unintended sexual intercourse, I } \\
\text { would advice emergency } \\
\text { contraceptive }\end{array}$} & Yes & $56(91.80)$ & 67 (91.78) & $123(91.79)$ & \multirow[b]{2}{*}{0.99} \\
\hline & No & 05 (8.19) & $06(8.22)$ & $11(8.21)$ & \\
\hline \multirow{2}{*}{$\begin{array}{l}\text { Do you think that there is a role of } \\
\text { emergency contraceptives in } \\
\text { increasing pre marital sexual } \\
\text { behaviour in adolescence }\end{array}$} & Yes & $51(83.61)$ & $57(78.08)$ & $108(80.59)$ & \multirow[b]{2}{*}{0.42} \\
\hline & No & $10(16.39)$ & $16(21.92)$ & $26(19.41)$ & \\
\hline \multirow{2}{*}{$\begin{array}{l}\text { Do you think widespread use of } \\
\text { emergency contraceptive will } \\
\text { increase prevalence of } \\
\text { HIV/AIDS/STDs }\end{array}$} & Yes & $45(73.77)$ & $46(63.01)$ & $91(67.91)$ & \multirow[b]{2}{*}{0.18} \\
\hline & No & $16(26.23)$ & 27 (36.99) & 43 (32.09) & \\
\hline \multirow{2}{*}{$\begin{array}{l}\text { Do you think that wider use of } \\
\text { contraceptives would affect ongoing } \\
\text { regular methods of contraceptives }\end{array}$} & Yes & $39(63.93)$ & $58(79.45)$ & 97 (72.39) & \multirow[b]{2}{*}{0.04} \\
\hline & No & $22(36.07)$ & $15(20.55)$ & $37(27.61)$ & \\
\hline \multirow{2}{*}{$\begin{array}{l}\text { Your willingness to use emergency } \\
\text { contraceptives in future }\end{array}$} & Yes & $38(62.29)$ & $58(79.45)$ & $96(71.64)$ & \multirow{2}{*}{0.02} \\
\hline & No & $23(37.70)$ & $15(20.55)$ & $38(28.36)$ & \\
\hline \multirow{2}{*}{$\begin{array}{l}\text { If no, reason for not using it because } \\
\text { of side effects }\end{array}$} & Yes & $18(78.26)$ & $13(86.67)$ & $31(81.58)$ & \multirow{2}{*}{0.55} \\
\hline & No & 05 (21.74) & $02(13.33)$ & 07 (18.42) & \\
\hline \multirow{4}{*}{$\begin{array}{l}\text { Do you think that emergency } \\
\text { contraceptives can affect baby } \\
\text { seriously if they don't properly work } \\
\text { Do you think that it is advisable to } \\
\text { advertise use of emergency } \\
\text { contraceptive on TV or mass media }\end{array}$} & Yes & $52(85.25)$ & $60(82.19)$ & $112(83.58)$ & \multirow[b]{2}{*}{0.63} \\
\hline & No & 09 (14.75) & $13(17.81)$ & $22(16.42)$ & \\
\hline & Yes & $47(77.05)$ & $68(93.15)$ & $115(85.82)$ & \multirow[b]{2}{*}{0.00} \\
\hline & No & $14(22.95)$ & $05(6.85)$ & $19(14.18)$ & \\
\hline $\begin{array}{l}\text { What is your overall attitude towards } \\
\text { emergency contraceptives }\end{array}$ & $\begin{array}{l}\text { Positive } \\
\text { Negative }\end{array}$ & $\begin{array}{l}48(78.69) \\
13(21.31)\end{array}$ & $\begin{array}{l}64(87.67) \\
09(12.33)\end{array}$ & $\begin{array}{l}112(83.58) \\
22(16.42)\end{array}$ & 0.16 \\
\hline
\end{tabular}

More than $90 \%$ of respondents of either sex were willing to recommend EC in case of an unintended sexual intercourse. About $80 \%$ of the respondents were positive about role of EC in increasing premarital sexual promiscuity in adolescents. In a similar vein, $67 \%$ of the respondents said that widespread use of EC may increase prevalence of HIV/AIDS/ STDs. Higher proportion of female respondents felt that wider use of EC would affect ongoing regular methods of contraceptives $(p<0.05)$. More females than males were willing to use EC in future $(\mathrm{p}<0.05) .83 \%$ of the respondents were of the opinion that EC can affect the newborn seriously in case of their failure. Higher proportion of females opined that EC should be advertised on mass media for better dissemination of knowledge among the masses $(\mathrm{p}<0.05)$. 
Overall attitude towards EC was positive $-87.6 \%$ in females and $78.6 \%$ in males (Table 3 ).

\section{DISCUSSION}

The present study assessed the medical student's knowledge and attitudes towards EC. As noted from the results of the study, all the participants had ever heard of EC. These results were found to be in agreement with the results reported by Iliyas $\mathrm{MC}$, Reddy $\mathrm{NR}$ et al and Relwani $\mathrm{N}$ et al. ${ }^{7-9}$ In contrast, Hoque ME et al reported that only $49.8 \%$ of the respondents had heard about EC prior to the study. ${ }^{10}$ About $60 \%$ of the respondents in the present study reported mass media as the main source of information for EC. However higher rates to the tune of $75 \%$ and $87.5 \%$ were found among respondents regarding mass media as the main source of information about EC in studies conducted by Ahmed FA et al and Iliyas MC respectively. ${ }^{5,7}$ However, in another study conducted by Akani C I et al in Nigeria among undergraduates college students, the main source of information about EC was through friends/peers. ${ }^{11}$

About three fourth of the respondents were aware of OCP use as EC but only one tenth of them were aware of IUCD as EC. These findings concur with an earlier study conducted in the same institution by Gupta RK et al. ${ }^{12}$ The findings are also consistent with those reported by Puri S et al from Chandigarh. ${ }^{13} 90 \%$ of the respondents were aware of the acceptable time to use EC after unprotected sex but Ahmed FA et al reported that only $64.4 \%$ respondent were aware about it. ${ }^{5}$ High doses of hormones in EC were reported by $72.3 \%$ of the respondents and similar results were reported by Reddy NR et al and Iliyas MC. ${ }^{7,8} 42.5 \%$ of the respondents were aware that EC prevents implantation and ovulation. Similar information was known to $41.4 \%$ of doctors in Kashmir valley and $50 \%$ of doctors in Delhi. ${ }^{14,15}$ Only $46.2 \%$ of the respondents were aware that pregnancy test is not required before EC prescription and $40 \%$ of respondents didn't know the effectiveness of EC. Both these relatively low levels of awareness among medical students is a cause of concern and needs immediate attention. Only 53\% replied in positive about the easy availability of EC which was in agreement to the results reported by Iliyas MC. ${ }^{7}$

$92 \%$ of the respondents would, recommend EC to a friend/relative in case of unintended sexual intercourse which reflects a strong positive attitude, while only $70.1 \%$ agreed to recommend EC use in future in a study conducted by Gajera AN et al. ${ }^{16} 80 \%$ of the respondents in the current study felt that EC may have some role in increasing premarital sexual behaviour in adolescence, where as only $29.5 \%$ of the respondents agreed that EC promotes promiscuity in a study conducted by Gajera AN et al in Government Medical College, Bhavnagar, Gujarat. ${ }^{16}$ There is need to disseminate in depth knowledge about EC which is not to be used too frequently or as an alternative to regular contraceptive methods. Also about $2 / 3^{\text {rd }}$ of the respondents had apprehension that wider use of EC may increase the prevalence of HIV/AIDS/STDs and may even affect the ongoing regular methods of contraceptives. Gajera AN et al reported that $37.1 \%$ of the undergraduate medical students considered it true that use of EC discourages the regular contraceptive use. ${ }^{16}$ Iliyas MC reported that $93 \%$ of the students felt that EC was not an effective routine method of contraception. ${ }^{7}$ Iliyas MC further reported that only $25 \%$ of the students felt that EC may increase the chance of STI/HIV infection among users. ${ }^{7}$ In a study conducted by Relwani $\mathrm{N}$ et al among engineering college girls in Nagpur, $39 \%$ of the respondents were of the opinion that providing ECP would discourage consist use of condom. ${ }^{9}$

About $28 \%$ were not willing to use EC in future, largely due to its side effects, is an indication that skill based learning about EC from early years of medical school can prove beneficial for the health care system in the long run. $85 \%$ of the respondents were of the opinion that EC be widely publicised on TV/ Mass media which will help its wider use. Overall, $83.5 \%$ of the respondents had positive attitude towards EC whereas Hoque ME et al reported that $63.2 \%$ of the respondents had positive attitude towards utilization of EC, as they would use it in future, if required and would recommend it to others. ${ }^{10}$

\section{Limitations}

Since the sample size is small and the study population consisted of students of only one college, the study results may not be generalizable. Because of the sensitive nature of the topic and self reporting, information bias could creep in. To minimise it, anonymity and confidentiality were ensured.

\section{CONCLUSION}

There was a low level of knowledge regarding EC on certain parameters among the medical students. Despite this, level of knowledge was found to be very good on some other parameters of knowledge. This patchy knowledge on the part of medical students which are in the mid-zone of their medical career needs to be taken with concern. They need to be imparted in depth knowledge about EC since their entry into medical stream which needs to be reinforced periodically over next few years till they reach internship.

\section{Funding: No funding sources Conflict of interest: None declared \\ Ethical approval: The study was approved by the Institutional Ethics Committee}

\section{REFERENCES}

1. Neinstein LS, Gordon MC, Katzman KD, Rosen SD, Woods RE. Adolescent Health Care: a practical 
guide.Edited by: Lippincott Williams and Wilkins.Philadelphia;2008:533-649.

2. Szarewski A, Guillebaud J. Contraception: A users guid. 3 ed. New York: Edited by Oxford University press;2002.

3. WHO: Contraception: Issues in adolescent health and development. Geneva;2004 Available at http://whqlibdoc.who.int/publications/2004/9241591 447_eng.pdf. Last accessed on 30-06-2017.

4. WHO and Gutmacher Institute: Facts on induced abortion world wide. 2007 Available at http://www.searo.who.int/LinkFiles/Publications_Fa cts_on_Induced_Abortion_Worldwide.pdf. Last accessed on 30-06-2017.

5. Ahmed FA, Moussa KM, Petterson KO. Assessing knowledge, attitude, and practice of emergency contraception: a cross-sectional study among Ethiopian undergraduate female students. BMC Public Health. 2012;12:110.

6. Tesfaye T, Tilahun T, Girma E. Knowledge, attitude and practice of emergency contraceptive among women who seek abortion care at Jimma University specialized hospital, southwest Ethiopia. BMC Womens Health. 2012;12:3.

7. Iliyas MC. A cross sectional study on awareness about emergency contraception among medical students in Kannur, Kerala, India. Int $\mathbf{J}$ Commun Med Public Health 2016;3:3216-9.

8. Reddy NR, Kishore SG, Basha SR. Knoweldge on Emergency Contraception Among Medical Students in Bangalore, Karnataka. J Evol Med Dent Sci. 2014;3(2):369-73.

9. Relwani N, Saoji A, Kasturwar NB, Nayse J, Junaid M, Dhatrak P. Emergency contraception: exploring the knowledge, attitude and practices of engineering college girls in Nagpur district of central India. Nat J Comm Med. 2012;3(1):14-19.
10. Hoque ME, Ghuman S. Knowledge, Practices, and Attitudes of Emergency Contraception among Female University Students in KwaZulu-Natal, South Africa. PLoS one. 2012;7(9):e46346.

11. Akani CI, Enyindah CE, Babatunde S. Emergency Contraception: Knowledge and Perception of Female undergraduates in the Niger Delta of Nigeria. In Ghana Med J. 2008:(2):68-70.

12. Gupta RK, Raina SK, Verma AK, Shora T. Emergency contraception: Knowledge and attitude toward its use among medical students of a medical college in North-West India. J Pharma Bioall Sci. 2016;8(3):235-9.

13. Puri S, Bhatia V, Swami HM, Singh A, Sehgal A, Kaur AP. Awareness of emergency contraceptionamong female college students in Chandigarh, India. Indian J Med Sci. 2007;61:33846.

14. Farooq F, Kadri SM, Gash BA. Emergency contraception: Knowledge of doctors in Kashmir valley. J Community Med. 2007;3:1-9.

15. Singh S, Mittal S, Anandalakshmy PN, Goel V. Emergency contraception: Knowledge and views of doctors in Delhi. Health Popul Perspect Issues. 2002;25:45-54

16. Gajera AN, Barvaliya MJ, Shukla A, Tripathi CB. Knowledge and attitude towards emergency contraception among undergraduate medical students. Int J Basic Clin Pharmacol. 2017;6:955-61.

Cite this article as: Gupta RK, Singh P, Kumari R, Langer B, Sharma P, Gupta R. Assessment of knowledge and attitude about emergency contraception: a cross sectional study among medical students in North India. Int J Reprod Contracept Obstet Gynecol 2017;6:4042-7. 